\title{
Die sinvolle aanddiens
}

\section{AC Barnard}

\section{Abstract}

A more meaningful evening service

We inherited the practice of the evening service (evening prayer), and with it the problem of its diminishing importance. Various factors contributed to this state of affairs. Guidelines for a more meaningful evening service, are:

* It must be a genuine church service

* It must have a different character from the morning service, and as such a freer character.

* The form should be varied and can have alternatively different accents: an ordinary morning service, a service with holy communion, a service with the accent on teaching, prayer, song, the main lines of the church work, confession and witness, discussion or fellowship/koinonia.

The watch word is proper preparation, good control, variation and responsibility.

As kerk het ons die gebruik geërf om 'n aanddiens of middagdiens of tweede diens te hou. Hierdie gebruik word as só belangrik beskou dat van elke lidmaat verwag word om, naas die oggenddiens, ook hierdie diens by te woon. Die verpligting rus op die kerkrade om sulke dienste te reël en van die predikante word verwag om hierdie dienste te lei.

Soos die oggenddiens, staan ook die aanddiens in die spervuur van kritiek. Die inrigting daarvan word bevraagteken, ja die diens as sodanig is in die gedrang. In die geval van die aanddiens kom 'n verdere vraag na vore naamlik, of so 'n diens naas die oggenddiens bestaansreg het.

\section{DIE AANDDIENS AL MEER IN DIE GEDRANG}

\section{1 'n Geringer bywoning as die oggenddiens}

Dit is ' $n$ algemene verskynsel dat die bywoning van die aanddiens veel swakker is as dié van die oggenddiens. Die bywoning in die aand is gemiddeld 'n kwart van dié in die oggend. 'n Ondersoek wat in 1985 
landswyd in die Nederduits Gereformeerde Kerk geloods is, het getoon dat die gemiddelde bywoning van die oggenddiens $35,78 \%$ was teenoor $9,35 \%$ van die aanddiens (Kerksensus 1985).

Studentegemeentes of stedelike gemeentes met baie jongmense het 'n veel groter bywoning in die aand. Dit beteken dat in baie ander gemeentes die bywoningsyfer baie swakker is as ' $n$ kwart van die van die oggenddiens. In veral plattelandse gemeentes dreig die aanddiens om dood te loop, en in baie gevalle is dit inderdaad reeds afgeskaf.

As gevolg van allerlei faktore is daar ' $n$ tendens dat die aanddiens in baie gemeentes steeds verder krimp en al meer sy betekenis verloor. Van 1981-1985 het die gemiddelde bywoning in die NG Kerk met $6,22 \%$ gedaal. Dit geskied veral oral waar nie besonderlik aandag aan die aanddiens gegee word nie. Ook van ons geld wat JT Bakker en GN Lammens van die posisie in Nederland skryf: dat '. . . we immers druk bezig zijn deze tweede dienst te verspelen. Het hoeft nog maar een paar jaar zo door te gaan en het probleem lost zich vanzelf op, eenvoudigweg omdat het er dan helemal niet meer is'.

\section{2 'n Bose sirkelgang}

Omdat minder mense die aanddiens bywoon, word dit verkeerdelik as minder belangrik beskou. Dus word daar minder tyd en kragte aan bestee in die beplanning en voorbereiding daarvan. In feite word dit ' $n$ 'tweede' diens of ' $n$ 'afskeep' diens.

Hoe minder aandag en sorg aan die aanddiens bestee word, hoe minder aantreklik en sinvol word dit. Mense voel dat die kerk nie erns maak met hierdie diens nie, met die gevolg dat die bywoningsyfer verder daal. Inderdaad is dit 'n bose sirkelgang.

Waar die bywoning van die aandienste daal, kom mense maklik daartoe dat twee of meer gemeentes gesamentlik 'n aanddiens hou. So word die persoonlike karakter daarvan verder ingeboet. Oplaas word dié diens maar afgeskaf.

Die agteruitgang van die aanddiens loop parallel met die klag dat die gemeente steeds passiewer, onmondiger en meer massaal word.

\section{FAKTORE WAT DIE POSISIE MET DIE AANDDIENS VERDER BEMOEILIK}

\subsection{Deel van 'n veel wyer probleem}

Die hele idee van die samekoms van die gemeente, die inhoud en inrigting daarvan, het vandag in die gedrang gekom. Vele probleme 
(waarop daar nie nou sal ingegaan word nie) geld ten opsigte van die oggenddiens en alle probleme wat hier geld, geld ook in sterker mate van die aanddiens.

\subsection{Die stroom van verwêreldliking}

Wêreldwyd is daar ' $n$ sterkerwordende stroom van denke en lewe aan die gang, naamlik dat die gees en gesindheid van hierdie wêreld in sy opstand teen God, die ware lewe en geloof in die harte van mense en in die kerk verstik. Dit is ' $n$ veelsydige beweging waar God al meer 'onttroon' word en ander magte in sy plek kom. Die mens self, word al meer die middelpunt van alles, ook van die godsdiens. Dit kom ook tot uitdrukking in die samekoms van die gemeente in die erediens.

\subsection{Die skeiding tussen geloof en lewe}

Die kloof tussen die geloof in Jesus Christus en die uitlewing daarvan in die daaglikse bestaan, word steeds groter. Wat lidmate in die week in die wêreld beleef, is so anders as die geloof waarvan die erediens op ' $n$ Sondag spreek. Dit word al moeiliker om wat in die erediens gebeur, te gebruik in die daaglikse lewe omdat die twee terreine al meer uitmekaar dryf. Die erediens word dan maklik wêreldvreemd, en die daaglikse lewe al meer 'wêrelds' en 'geloofsvreemd'.

\section{4 'n Gemeente van ontvangers}

'n Patroon van kerklike lewe het ontwikkel waar baie lidmate onbetrokke is. Oplaas kan of wil hulle nie meer aktief aan die erediens deel hê nie. Hulle het passiewe toeskouers, hoorders geword.

So nie kom die lidmate na die erediens slegs om iets te ontvang. Met dit wat Sondag na Sondag uit die erediens verkry word, word egter niks gedoen nie. Daaruit word nie geleef nie, dit word nie uitgegee nie. Omdat hulle hierdie geestelike voedsel nie omsit in energie vir die arbeid in die kerk en in die wêreld nie, verloor hulle die aptyt om verdere geestelike voedsel in te neem. Hulle het dit nie nodig nie. Waarom dan nog 'n tweede erediens bywoon?

Dikwels gebeur dit dat hulle dan na byeenkomste gaan waar hulle nie slegs toeskouers en ontvangers is nie, maar deelnemers en werkers word. 


\subsection{Die aanddiens 'n blote doeblet van die oggenddiens}

Die kerk kan self die aanddiens devalueer deur in gebreke te bly om daaraan ' $n$ eie karakter te verleen. ' $n$ Verbeeldinglose inrigting van die aanddiens of ' $n$ swak-beplande en doellose replika van die oggenddiens, is die sterkste faktor wat die ondermyning daarvan bewerk. So 'n diens sal nie vir lidmate sinvol wees of hulle daarheen aantrek nie.

\section{6 'n Ander gebruik van die meer vrye tyd}

Tans het mense baie meer vrye tyd as voorheen. Mens sou verwag dat hierdie toename in vrye tyd gebruik sou word om die tweede diens ook by te woon. Dit word egter vir ander dinge gebruik, soos vir besoeke of om besoeke te ontvang, vir sport, ontspanning, televisie-kyk, gesinsamesyn, ensovoorts. Die toename in vrye tyd het nie 'n toename in erediensbywoning en dan veral in die bywoning van die aanddiens tot gevolg gehad nie.

\subsection{Sterk konkurrensie deur die media}

Die media, soos die radio en veral die televisie, met al die interessante luister- en kykprogramme, het 'n magtige konkurrent geword vir die aanddiens. Waar die aanddiens nie iets bied wat anders is as die radio en televisie nie en waar mense nie iets ontvang wat hulle nêrens anders kan kry nie, soos 'n gevoel van geborgenheid en selfbelewing nie, daar is dit begryplik dat hulle eerder na die programme van die radio en televisie sal luister en sal kyk.

\subsection{Allerlei praktiese probleme}

Daar is ' $n$ aantal praktiese probleme wat die bywoning van die aanddiens bemoeilik, soos die koste om twee keer per Sondag na die erediens te kom waar mense ver van die kerk bly en die veiligheidsrisiko om in die aand uit te gaan of op pad te wees.

\section{IS DIE AANDDIENS WERKLIK NODIG?}

\subsection{Die lidmate word verwag, maar hulle kom nie}

In die kerk geld die eis duidelik dat daar twee eredienste op 'n Sondag gehou moet word en dat van die lidmate verwag word om dit by te woon. 
Op allerlei maniere word die lidmate aangespreek om ook die aanddiens by te woon: in preke, by huisbesoek, by die katkisasie. In die verslae van kerkvisitasie, ampsbediening en evangelisasie, word rekenskap gevra of aanddienste gehou is en wat die bywoning daarvan was.

Ten spyte van al hierdie pogings, is daar die groot meerderheid lidmate wat nooit of selde na die aanddiens kom.

Is diegene wat gereeld na die oggenddienste kom, maar nie die aanddiens bywoon nie, minder getrou as diegene wat na albei kom? Is so ' $n$ persoon minder toegewyd, minder gelowig en dus ' $n$ slegter lidmaat? Hier word inderdaad gevra na die hart van gelowig-wees.

\subsection{Is twee volwaardige eredienste op 'n Sondag verteerbaar?}

Die vraag word dikwels gevra of 'n lidmaat twee goeie, sinvolle dienste, met alles wat daarin aangebied word, kan verwerk. Daarmee saam word twyfel uitgespreek of so iets werklik nodig sou wees.

Hierdie probleem word groter as die twee dienste in wese dieselfde karakter, strekking en inrigting het. Wat bring die tweede diens wat die eerste diens nie reeds gegee het nie? 'n Probleem wat hiermee gepaard gaan, is dat mense die erediens bywoon as passiewe ontvangers en niks uitrig met dit wat hulle ontvang het nie, soos iemand wat swaar etes neem, maar onaktief is. Baie gou doen so 'n persoon slegte spysvertering op. Daar tree geestelike indigestie in. Al die preke en dienste word aangebied, maar die gemeente doen niks daarmee nie. Party vromes word daardeur vromer en heiliges word heiliger, maar hierdie vroomheid en heiligheid word nie oorgedra tot in die konkrete lewe en werk nie.

3.3 Die vraag of twee goedvoorbereide dienste per week moontlik is

Van die kant van die persone wat die twee dienste per Sondag sinvol moet inrig, kom soms die bedenking dat dit te veel gevra is. Om ' $n$ werklik sinvolle erediens te beplan en voor te berei, insluitende die preek, neem veel tyd en kragte in beslag en vereis ' $n$ groot geestelike kapitaal. Vir baie leraars wat alleen in 'n gemeente staan, is dit ' $n$ baie moeilike taak om uit te voer by al sy ander gemeentewerk. Onvermydelik ly die tweede diens daaronder en verkry dit minder aandag en beplanning. 
Inderdaad stel twee dienste hoë eise, maar die vraag bly of dit nie die leraar se hoogste prioriteit moet wees nie. Hy hoef ook nie alles alleen te doen nie.

\subsection{Te maklik word die weg van die minste weerstand gevolg}

Omdat dit moeiliker geword het vir mense om die aanddiens by te woon en die opkoms inderdaad skraler is as dié van die oggend, is die versoeking groot om maar die aanddiens te laat verval. Daarmee word in feite erken dat die probleme so groot is dat die aanddiens nie meer sinvol ingerig kan word nie. So word die weg van die minste weerstand gevolg. Dieselfde argumente sou later ook ten opsigte van die oggenddiens gebruik kon word.

\subsection{Dieselfde teologiese basis as vir die oggenddiens}

Die innerlike noodsaaklikheid vir die hou van 'n aanddiens is dieselfde as dié vir die hou van die oggenddiens. Die wonder van die verlossing deur Christus, bring die innerlike aandrang om Hom in die openbaar saam met ander gelowiges te dien. Christus trek as 't ware almal wat in Hom glo, ook in die openbaar saam. Hulle het 'n nuwe gemeenskap geword wat mekaar nodig het en saam hulle Here wil dien en tot sy beskikking wil staan in die wêreld.

\section{6 'n Stuk kerklike lewe}

Vir solank as wat die Christelike Kerk bestaan, is daar ook aandbyeenkomste in een of ander vorm gehou. Nie allerlei wette of besluite het hulle daartoe gebring nie, maar hulle het steeds die sterk innerlike drang daartoe gevoel en die behoefte daaraan gehad. Deur die hele geskiedenis van die kerk het dit ' $n$ wesenlike deel van die kerklike lewe en bestaan geword.

Die aanddiens is, naas die oggenddiens, ' $n$ besondere geleentheid om die Here te dien en te aanbid, om in die geloof opgebou te word, om vir die arbeid toegerus te word en om die diens en getuienis in die wêreld te kan lewer. Wie die aanddiens laat vaar, laat ' $n$ belangrike deel van die lewe en werk van die kerk los; so word ook die geleenthede tot opbou van die gemeente, die versterking van die geloof en die verkondiging van die evangelie, gehalveer. 


\subsection{Die aanddiens 'n geleentheid vir diegene wat nie die oggend kon kom nie}

Die aanddiens voorsien in 'n belangrike behoefte vir diegene wat skofte werk of deur ander omstandighede verhinder word om die oggenddiens by te woon. Hulle kry só inderdaad 'n geleentheid om die Here te kom dien en aanbid.

Ouers met klein kinders moet beurte maak om na die kerk te kom. Waar die een in die oggend kom, kan die ander die aanddiens bywoon. Indien daar by die kerk 'n oppasdiens gereël word waar die klein kinders sinvol onder sorg gehou kan word terwyl die ouers saam na die erediens gaan, is die noodsaak om afsonderlik na die kerk te gaan verminder, maar nou kan hulle juis saam albei dienste bywoon.

Steeds is daar ' $n$ belangrike deel van die gemeente wat wel ' $n$ behoefte het aan die aanddiens en inderdaad daarheen kom. In stadsgemeentes is daar ' $n$ groot persentasie tieners en ander jongmense wat saans na die erediens kom. Die aanddiens bly steeds in aanvraag.

\section{8 'n Diens met 'n eie karakter}

Die waarde en betekenis van die aanddiens word verhoog waar dit gesien en ingerig word as 'n diens met 'n eie karakter. Hier kan aandag gegee word aan die sake wat nie in die oggenddiens aandag of genoegsame aandag kan kry nie. Oral is dit merkbaar dat as aan die aanddiens besondere aandag en sorg bestee word en hier aan ander behoeftes uitdrukking gegee word, die mense daarheen kom. Die aanddiens hoef dus nie te verval nie, maar moet veel meer benut word en die geleentheid aangegryp word om daaraan 'n eie karakter te gee.

\section{9 'n Uitdaging wat hoopvol aangepak moet word}

Die aanddiens en die sinvolle inrigting daarvan skep inderdaad ernstige probleme. Dit vereis deeglike beplanning, veel aandag en 'n nuwe benadering. Dit moet nie gesien word as rede om dit maar te laat doodloop nie. Dit moet eerder aangegryp word as ' $n$ besondere uitdaging. Daar is soveel geleenthede om daarvan 'n sinvolle byeenkoms van die gemeente te maak. Waar die uitdaging aangegryp word met oortuiging en met verwagting, gebeur daar groot dinge. 'n Nuwe, interessante en aktuele aanddiens trek vandag nog mense aan en dit word ' $n$ besondere geleentheid in die lewe en werk van die kerk.

Die vraag na die bestaansreg van die aanddiens is tegelyk die vraag 
na die wese en lewe van die kerk. Dit is ook die vraag na die geloofslewe van die lidmate: Hoe diep loop hulle geloof?

Die diepste motiveringe tot die aanddiens is om deel te hê aan die verlossing van Christus, die vervulling met die Heilige Gees wat alles nuut maak, die allernouste binding aan Christus, die bereidheid om te leer en gebruik te word, en die gewilligheid om te dien en te getuig.

\section{DIE HISTORIESE WORTELS VAN DIE AANDDIENS}

Die geskiedenis mag nooit as norm dien vir die bepaling of die aanddiens bestaansreg het of nie, maar dit toon tog hoe die kerk van die begin daaroor gedink het en dit ingerig het. Die geskiedenis bepaal verder ook hoe die kerk die aanddiens vandag inrig en daaroor dink. Ons tref drie groot historiese wortels vir die aanddiens aan:

\subsection{Die aanddiens as gebedsdiens}

\subsubsection{Gebed in die aand en nag}

Die oudste wortel van die aanddiens is die gebed van die gelowige in die aand of nag. By die gelowige van ouds was daar ' $n$ besondere behoefte om die Here te dank en te dien in die aand voordat hy gaan slaap. Dit was die uitdrukking van 'n diep geloof en die reken met sy besondere sorg.

\subsubsection{Die aandgebed by die tempel}

Hierdie gebruik van die aandgebed het 'n bepaalde struktuur verkry in die bring van die aandoffers na die tempel (soos ook die môre-offers). Hiermee het saamgegaan die aandgebede by die tempel (daar was ook die môregebede). Die Jode het die vaste gebruik geken dat in die aand geoffer en gebid is vir en in naam van die volk.

\subsubsection{Die aandgebed by die sinagoge}

In die sinagoge is drie gebedsbyeenkomste per dag vir die volk gehou waaraan hulle self deelgeneem het: ' $n$ môre-, middag- en ' $n$ aandgebed. Hier het die geloofsbelydenis, die schema en die gebed, die tefilla, 'n sentrale plek ingeneem. Die byeenkomste by die begin en uitgang van die sabbat (aand), is besonderlik uitgebou. Die kern van hierdie byeenkomste was die geloofsbelydenis, omraam deur allerlei benediksies, die sentrale gebed, die tefilla of gebed van agttien, saam met ander 
gebede en veral verskeie Psalms wat gebid en gesing is, die lees van die Tora en die uitleg daarvan. Die beoefening van die gebed het egter ' $n$ hoofaksent verkry.

\subsubsection{Die aandbyeenkomste van die eerste Christene}

Die eerste Christene het naas die byeenkomste vroeg op 'n Sondagoggend voor werk, ook saans saamgekom. Dan is 'n gemeenskaplike maaltyd genuttig, waarby die nagmaal, met 'n duiding daarvan, aangesluit het.

Later is die erediens met nagmaal na die Sondagoggend verskuif. Nou het die byeenkoms in die aand al meer die karakter gekry van 'n gebedsbyeenkoms. Hier is die gebed in sy verskillende vorms beoefen, uit die Skrif gelees en liedere gesing.

\subsubsection{Gebedstye in die aand}

Die gebruik van die Jode om op bepaalde tye elke dag byeenkomste vir gebed te hou - gebedstye-, is deur die Christene nagevolg. So was daar gou ook drie gebedstye per dag: ' $n$ môre-, middag- en aandgebed. Veral die Sondagaand se gebedstyd het 'n sterker klem gekry.

Oplaas is die drie gebedstye per dag uitgebrei na sewe sulke gebedstye per dag in die Rooms-Katolieke Kerk. In die kloosters bestaan dit vandag nog so.

Die gebruik van 'n aantal gebedstye per dag het navolging gevind in die Lutherse Kerk en in die Anglikaanse Kerk, waar dit egter tot twee gereduseer is.

Deurgaans het die aangebed, waar die Bybel sistematies gelees is, liedere gesing is (veral die Psalms) en die gebed as formuliergebed en as vrye gebed dan beoefen is, die karakter gedra van 'n gebedsbyeenkoms. Vandag kom die aandgebed nog in verskillende vorms voor as: Vesper, Abendgebet, Evening Prayer/Evensong, Avondgebed.

\subsection{Die aanddiens as 'n leerdiens}

\subsubsection{Leerdiens/kategetiese diens reeds voor die Reformasie}

Reeds voor die Reformasie was leerdienste in die Roomse Kerk bekend. Dit het bestaan as deel van die Mis of as 'n selfstandige diens naas die Mis. Hier is die vier 'kategetiese stukke', te wete die Dekaloog, die Credo/Geloofsbelydenis, die Onse Vader en die sakramente behandel.

\subsubsection{Leerdiens deur die reformatore}

Die verskillende reformatore het die bestaande vesper of aandgebed in die Roomse Kerk vervang met 'n leerdiens of kategetiese diens. Dit het 
twee kenmerke in een gehad: Dit was eerstens 'n geleentheid vir kategese van die jeug en tegelyk is die kategismusse, wat in hierdie tyd opgespring het, uitgelê deur middel van kategismusprediking.

- Luther lê hom toe op die uitleg van die kategismus, maar daarnaas gebruik hy ook die aandgebed, met klem op die gebed deur die gemeente.

- Zwingli hou, naas die oggenddienste, byeenkomste in die middag in die plek van die aandgebed, waar die Bybel gelees, gebid, die Psalms gelees en die geloofsbelydenis gedoen is.

- Bucer het 'n middagdiens en 'n diens vir die kinders ('Der Kinderbericht') gehou, waar die kategismus uitgelê en die kinders daaroor ondervra is. Hierby het hy ook die aandgebed, die vesper, gehou, wat didakties van aard was, met liedere en 'n kollekta-gebed.

- Calvyn laat vaar ook die gebedstye soos dit in die Roomse Kerk gebruiklik was. In die plek daarvan stel hy preekdienste in. Tydens die byeenkoms van die gemeente in die middag is die kinders uit die kategismus wat hy opgestel het, ondervra, en is uit die kategismus gepreek.

- á Lasco, Micron, Pollanus volg almal die voorbeeld van Calvyn en rig die middagdiens in met die oog op die kategese van die kinders en kategismusprediking vir die gemeente. Ook John Knox het hierdie patroon gevolg.

\subsubsection{Aanddiens/Middagdiens as leerdiens in Nederland}

Sedert die deurbraak van die Reformasie in Nederland, is die gebruik van Calvyn nagevolg. In die middag is die Skrif eers uitgelê. Dan sê die kinders een vir een die vrae en antwoorde van die Heidelbergse Kategismus op. Daarna lê die leraar die vrae en antwoorde van die kategismus vir die gemeente uit.

Die verskillende sinodes in Nederland, soos die Sinodes van Dordtrecht van 1574 en 1578, die Sinode van Middelburg van 1581, en verskeie latere sinodes, het bepaal dat die kategismus in die prediking by die middagdiens aan die orde moes kom. Dit was voluit 'n leerdiens in die vorm van kategismusprediking.

Deur die eeue heen, tot vandag, het die middagdiens en later die aanddiens die karakter van 'n leerdiens behou in 'n deel van die kerke in Nederland.

Die gebruik om in die middag 'n leerdiens te hou waar kategismusprediking in die middelpunt staan, het ons geërf. Dit het in Suid-Afrika 'n mate van navolging gevind. 


\subsection{Die aanddiens as 'n preekdiens}

\subsubsection{John Wesley begin met 'aand' dienste}

Wesley breek nie meteens met die Anglikaanse Kerk nie. Hy moedig sy aanhangers aan om eers die Evening Prayer in die Anglikaanse Kerk by te woon, waarna hy hulle byeen bring vir 'n byeekoms in die aand. In hierdie tyd is gaslampe uitgevind en dit het dienste in die aand moontlik gemaak.

\subsubsection{Preekdienste in die aand}

Hierdie aanddienste word ingerig as preekdienste. In hierdie dienste staan die revival-preek in die middelpunt, met die klem op bekering.

Hierdie preekdienste het uitgegroei tot evangelisasiedienste van die Methodiste Kerk in die groter sentra. Ander kerke het hierdie gebruik nagevolg.

\section{RIGLYNE VIR DIE AANDDIENS UIT DIE SKRIF EN GESKIEDENIS}

\subsection{Geen voorskrif uit die Skrif nie}

Soos vir die oggenddiens vind ons ook geen voorskrif in die Nuwe Testament vir die aanddiens nie. Daar is nêrens 'n wet wat sê dat so 'n diens gehou moet word of hoe dit ingerig moet word nie.

Dat Christene byeenkom - in die oggend en in die aand - is die gevolg van die groot verandering wat Jesus in die lewe van ' $n$ mens bring. Hierdie verandering bring die gelowiges byeen om met Hom en met mekaar saam te wees. Omdat iets wonderliks met hulle gebeur het, kom hulle byeen om

- Hom te dien en te eer;

- wat hulle ontvang het met andere te deel;

- dit uit te bou en te laat groei;

- dit in die praktyk in werking te stel;

- dit te beleef en te vier;

- mekaar te help en te versterk, en

- deur die ander gevorm en gebou te word.

Die Nuwe Testament gee wel duidelike beginsels vir die byeenkomste van die gelowiges. Hierdie beginsels moet so goed as moontlik in die 
Skrif nagegaan word en dan in die praktyk toegepas word. Elke kerk moet hierdie beginsels aanwend volgens die node van die praktyk. Hier kom vindingrykheid ook te pas. Die byeenkomste moet só verloop dat die gang van die evangelie nie daardeur verhinder word nie, maar juis bevorder word.

Verder het die eerste Christene die voorbeeld van die tempeldiens en die sinagogediens gehad. Veral die sinagogediens is nagevolg, maar daaraan is 'n nuwe inhoud en nuwe vorm gegee.

\section{2 'n Egte erediens}

Soos vir die oggenddiens, moet ook die eis vir die aanddiens vasgehou word, naamlik dat dit ' $n$ egte erediens moet wees. As 'n erediens dra dit minstens die volgende kenmerke:

- Dit is die samekoms van die gemeente om die Here in die openbaar te dien. Tegelyk is hierdie samekoms die antwoord op die werk van Christus. Hý roep die gemeente byeen en stig hierdie byeenkoms.

- Hierdie samekoms lei tot die ontmoeting tussen Christus en sy gemeente.

- Die byeenkoms verloop in die vorm van 'n gesprek tussen Christus en sy gemeente, dit wil sê daar is woord en weerwoord.

- In en deur die gesprek word die gawes van Christus op verskillende maniere uitgedeel.

- Deelname deur die gemeente aan die hele gebeure van die erediens. Die gemeente is ' $n$ volwaardige party in die erediens. Hulle mag deelneem en handel omdat Christus eerste gewerk en gehandel het en hulle mag en moet daarin deel. Dit is die onvervreembare reg van die gemeente om self betrokke te wees en self deel te neem.

Hierdie deelname is in die eerste plek gesamentlik, korporatief. Die gemeente tree as gemeente op.

Elke lidmaat het gawes van die Here ontvang en hierdie gawes moet ook in diens van die gemeente gestel word.

Die deelname deur die gemeente geskied onder die leiding van die besondere ampte.

- In alles neem die Bybel die sentrale plek in. Hierdie Woord moet gelees en bedien word. Die Bybel is die waarmerk, die legitimasie vir die egtheid van hierdie byeenkoms.

- Die gebed, gesproke sowel as gesonge (die lied) is 'n wesenlike kenmerk van die erediens. 
- Dit behels ook die voeding en oefening van die gemeente tot lewe, opbou, groei, diens en getuienis.

- Aan die spits van alles staan altyd die eer en verheerliking van God.

\subsection{Verskillende vorms na die eis van omstandighede}

Uit die Nuwe Testament en die geskiedenis van die kerk blyk dit duidelik dat die aanddiens verskillende vorms kan aanneem en aangeneem het. Die omstandighede van die kerk en bepaalde behoeftes het daartoe meegespreek. Ons kry veral die volgende vorms:

- huisbyeenkomste in die Nuwe Testament;

- gebedsbyeenkomste in verskillende vorms;

- leerdienste, met lering, onderrig en toerusting;

- preekdienste, toegespits op die bekering van die vervreemde, en

- 'n bonte verskeidenheid van eksperimente vandag.

\section{4 'n Byeenkoms met 'n eie karakter}

Die aanddiens is deurgaans in die geskiedenis naas die oggenddiens gehou. Hoewel die aanddiens verskillende vorms aangeneem het, het dit steeds ' $n$ ander karakter en vorm as die oggenddiens gehad. Die kerk het aangevoel dat die tweede byeenkoms ' $n$ ander doel het en ander kenmerke vertoon as die oggenddiens.

Vir ons behoort dit ook as riglyn te dien dat die aanddiens 'n eie karakter en gestalte moet hê, anders as die van oggenddiens.

Behalwe by uitsondering, mag die aanddiens nie maar net ' $n$ replika, 'n doeblet van die oggenddiens wees nie. Tereg skryf AFN Lekkerkerker: 'Een kerk, die van de Zondagavonddienste een herhaling maakt van de Zondagmorgendienst, is bezig de grond onder deze avonddienst weg te graven.'

Hierdie eie karakter van die aanddiens moet rekening hou met die bestaande oggenddiens en die besondere behoeftes van die kerk. Daarby kan die eie karakter van die aanddiens op verskillende maniere tot uitdrukking kom. Onvermydelik bring dit mee dat die aanddiens besondere aandag, beplanning en 'n eie inkleding moet kry.

$\mathrm{Om}$ aan hierdie beginsel uitdrukking te gee, word hieronder verskillende moontlike maniere van inrigting aangegee. Verskillende vorms van Woordbediening kan ook gebruik word. Daar moet egter steeds die eis gestel word van 'n liturgiese eenheid wat doelgerig na 'n spits lei en van ' $n$ ordelike en verantwoordelike inrigting van die aanddiens. 


\section{5 'n Byeenkoms met 'n vryer karakter}

Teenoor die inrigting van die oggenddiens het die aanddiens deurgaans 'n vryer en spontaner karakter gehad. Die vorm was minder strak, met ' $n$ groter mate van spontaneïteit. Hierdie beginsel behoort ons in ' $n$ groter mate te lei by die inrigting van die aanddiens. In elke geval is dit veel meer volgens die gees en gesindheid van die Nuwe Testament.

Die strak vorm van die oggenddiens spreek meer uit tye van geestelike insinking en ander motiewe as die gesonde Bybelse gees. Orde is noodsaaklik, maar moet steeds gepaard gaan met vryheid, vastigheid moet tegelyk variasie insluit.

\section{RIGLYNE VIR 'N SINVOLLE INRIGTING VAN DIE AANDDIENS}

\subsection{Die aanddiens as 'n gewone erediens}

Die behoefte sal steeds bestaan om by geleentheid 'n gewone erediens, soos op 'n Sondagmôre, in die aand te hou. Niemand sal aan die waarde daarvan twyfel nie, maar dan moet dit nie die heersende patroon wees nie.

\subsection{Die aanddiens as volledige diens}

Ruimte moet ook gelaat word om by geleentheid in die aand ' $n$ volledige diens te hê, dit wil sê die diens met die nagmaal daarby. In stedelike gemeentes en gemeentes waar baie lidmate skofte werk, kan so ' $n$ diens by geleentheid ' $n$ belangrike doel dien.

\subsection{Die aanddiens met die klem op die leer}

Die aanddiens het ' $n$ belangrike funksie as leerdiens. Hier is ' $n$ geleentheid vir kategismusprediking. Dit sal egter op 'n nuwe en fris manier aan die orde moet kom.

Nie slegs aan die kategismus nie, maar ook aan die leer as geheel sal aandag gegee moet word.

Uit die Skrif sal daar, aan die hand van die kerk se leer en belydenis, antwoorde gegee moet word op aktuele vrae. Tersakekundige informasie is dringend nodig.

Lering en onderrig impliseer: 
- toerusting;

- oefening;

- bespreking;

- oudio-visuele hulpmiddels.

Om leerdienste sinvol in te rig, is verder nodig dat daar geleentheid moet wees vir meerdere deelname deur die lidmate en vir die funksionering van groepe.

\subsection{Die aanddiens met die klem op die gebed}

Hier word nie slegs oor gebed gepraat nie, maar die gebed op veelvoudige wyse beoefen:

Gebed na sy verskillende elemente kry besondere aandag:

- verootmoediging en skuldbelydenis;

- daadwerklike voorbidding vir algemene en persoonlike node;

- danksegging vir alle tydelike en geestelike gawes;

- epiklese of die inroeping van die werking van die Gees, en

- lofprysing, aanbidding en verheerliking van God.

Die verskillende wyses van gebed behoort gebruik te word:

- vrye gebede deur die voorgangers en deur die lidmate;

- formuliergebede;

- 'n kombinasie van albei bogenoemdes;

- verskillende bestaande gebede wat aangepas word, soos: litanie, kollekta, prefatio, en andere;

- gesamentlike gebede;

- stilgebede, en

- gebed in groepe.

Deeglik beplande gebed geskied deur die gemeente onder die leiding van die liturg en ander besondere ampte.

\subsection{Die aanddiens met die klem op die gesonge gebed - die lied}

Sang het ' $n$ groot krag en dra veel by om die boodskap skerper te stel en dit dieper in die hart in te dra en ook langer te laat onthou. Die note maak die woorde lewend, het Luther tereg gesê. Sang doen veel om 'n atmosfeer te skep en mense hulle geloof sterker te laat beleef. 
Tydens die diens word die boodskap deur middel van sang in verskillende vorms oorgedra:

- sang as antwoord op die aanspreke van God - gesonge gebed;

- sang as verkondiging van die evangelie op baie maniere en in baie toonaarde;

- sang deur die gemeente;

- sang deur groepe en kore en in besondere gevalle deur enkelinge;

- beurtsang of antifoniese sang;

- refreine of responsoriese sang;

- woord, lied en musiek in 'n groot eenheid - 'n deklamatorium;

- sang ondersteun deur gepaste musiek, en

- sang met oorgawe en met lus.

6.6 Die aanddiens met die klem op die groot werksaamhede van die kerk

Die leer en belydenis van die kerk bring die gemeente vanself tot die daad en die aksie, tot die groot werksaamhede van die kerk waarin die geloof gestalte kry. Hierdie dade en aksies weer, impliseer 'n groter betrokkenheid van almal by die gebed.

Die aanddiens is ' $n$ kostelike geleentheid om afwisselend die groot aksies van die kerk aan die orde te stel en die betrokkenheid van die lidmate daarby uit te spel:

- evangelisasie;

- sending;

- jeugwerk en jeugdienste;

- diens van barmhartigheid, en

- leer en aktuele sake.

By hierdie geleenthede word nie slegs oor die werk gepraat nie, maar die lidmate word daarby betrek. Dit bring mee:

- toerusting;

- inoefening;

- bespreking;

- gebed.

6.7 Die aanddiens met die klem op belydenis en getuienis

\subsubsection{Belydenis}

Belydenis in die erediens en dan veral tydens die aanddiens, het ' $n$ regmatige plek. Belydenis in sy verskillende betekenisse behoort aan 
die orde te kom:

- openbare belydenis van mense wat tot geloof in Jesus Christus gekom het;

- reëlmatige openbare belydenis deur die gemeente van dit wat hulle glo as ' $n$ bevestiging van hierdie geloof en bekendmaking van hierdie geloof teenoor die wêreld;

- gemeenskaplike belydenis van skuld, wat op verskillende maniere gedoen kan word;

- belydenis van God se liefde en sorg, en die erkenning van sy voorsienigheid en bewaring.

\subsubsection{Getuienis}

Belydenis en getuienis sluit nou by mekaar aan, maar elkeen het tog 'n eie aksent. Getuienis aangaande Jesus Christus is ' $n$ baie sterk opdrag aan die kerk en aan die gelowiges afsonderlik.

- Elke gelowige is 'n getuie van Jesus Christus in die wêreld, en elke gelowige moet 'n getuienis hê aangaande Jesus Christus;

- Om te getuig en om 'n getuienis te hê, is 'n juridiese begrip:

- 'n getuie is 'n oog-en oorgetuie;

- hy spreek van wat hy gesien en gehoor het;

- waar dit in die wêreld gaan om die saak van Jesus Christus, word die getuies geroep om aangaande Hom te spreek van wat hulle self 'gesien' en 'gehoor' het;

- die getuie is bereid om met die eie lewe in te staan vir die egtheid van sy getuienis;

- die getuie spreek

- nie die eie outobiografie uit nie, maar die 'biografie' van Jesus;

- van die groot dade van God, veral soos dit tot uitdrukking gekom het in die koms van Jesus Christus na die wêreld en in sy verlossingswerk;

- die getuienis geskied:

- in die wêreld;

- voor die mense;

- oral waar dit om die saak van Jesus Christus gaan;

- deur die woord op baie maniere;

- deur die daad, die konkrete lewe, die handel en wandel.

- Getuienis in die erediens?

- As gevolg van allerlei misbruike is daar 'n groot huiwering by die kerk om getuienis in die erediens 'n plek te gee. 
- 'n Geleentheid vir getuienis na die erediens, waar in groepe spontaan oor die geloof en die implikasies daarvan gepraat word, behoort gegee te word.

- Misbruik van 'n saak hef egter nie die gebruik daarvan op nie, daarom behoort ook ' $n$ geleentheid ingeruim te word vir getuienis in die erediens onder die volgende voorwaardes:

- slegs by besondere geleenthede en nie as 'n staande praktyk nie;

- getuienis moet in die Bybelse sin verstaan word;

- dit moet liturgies verantwoord wees, inpas in die hele gang van die gesprek tussen die Here en sy gemeente;

- die getuienis moet gekontroleer en beheer word.

\subsection{Die aanddiens met die klem op samespreking}

Nog 'n wyse van inrigting van die aanddiens sluit sterk aan by die leerdiens, maar hier lê die aksent sterker op die samespreking in die diens en dit nie slegs by 'n aspek van die kerk se leer nie, maar waar ook sake rakende die lewe van die kerk aan die orde kom.

By besondere geleenthede word die erediens só ingerig dat dit meer die karakter dra van ' $n$ konferensie of samespreking oor 'n aktuele onderwerp wat met die gemeente deurgepraat word. Die erediens kry dan 'n vryer karakter.

Hierdie dienste moet steeds egte eredienste bly, dus samekomste van die gemeente, waar die lied, die gebed en veral die Woordbediening nie gemis mag word nie. Hoewel 'n formele preek nie gelewer word nie, moet dit egte Woordbediening wees. Die lig van die Skrif moet helder in die konkrete werklikheid spreek, sodat die gemeente daarmee en daaruit kan lewe.

Hier sal ook groter deelname deur die gemeente kan plaasvind. Lidmate kan 'n bydrae lewer of aan die bespreking deelneem. Die bespreking kan geskied in die groot groep of in kleiner groepe.

Die verband tussen geloof en lewe, en tussen leer en lewe kan hier uitgespel en ingeoefen word. Daar word nie slegs goedbedoelde raad gegee of pligte opgelê nie. Die gelowiges leer om die evangelie so te verstaan en so daardeur aangespreek te word, dat hulle dit in die konkrete lewe kan uitlewe en na ander deurgee.

Ook hier moet goeie leiding van die leraar uitgaan en moet die byeenkoms stylvol ingerig word. 


\subsection{Die klem deurgaans op die onderlinge gemeenskap - koinonia}

By die verskillende moontlikhede vir die inrigting van die aanddiens, moet die klem deurgaans sterk gelê word op die onderlinge gemeenskap tussen die gelowiges en die werklike belewing daarvan - in die erediens, maar ook daarbuite.

Egte gemeenskap beteken dat die lidmate nie maar as 'n amorfe groep mense saamgebring word sonder ' $n$ innerlike binding aan mekaar nie. Hulle moet saamkom in die besef dat hulle ' $n$ groot gesin van God is en broers en susters van mekaar. Meer nog, hulle moet hierdie onderlinge gemeenskap ervaar en daardeur versterk en opgebou word. Die onnatuurlike styfheid en indiwidualisme moet oorwin word.

Egte gemeenskap bestaan waar ons saam in Christus glo, Hom saam dien, saam van Hom getuig en Hom saam aanbid. Dit word versterk deur die omgang met die Woord en deur die werking van die Heilige Gees. Eweneens word dit versterk waar die gelowiges mekaar ken, met mekaar praat, mekaar se lewe en omstandighede ken, mekaar help, opbou en teregwys.

\subsection{Die groot belang van gesonde afwisseling}

Die verskillende moontlikhede vir die inkleding van die aanddiens en waar die klem op verskillende sake gelê kan word, is bedoel om gebruik te word sodat die aanddiens ' $n$ groter betekenis in die lewe en werk van die kerk kan kry.

Waar 'n gemeente net maar een moontlikheid sou kies en steeds daarmee sou volhard, beteken dit 'n groot verarming. Gou verloor dit aantreklikheid. Die geheim is gesonde variasie. So kan die gemeente groei, en kom ook die verskillende node en behoeftes van lidmate aan die orde. So word die gemeente versterk, verryk en opgebou.

\subsection{Orde, toesig en verantwoordelikheid}

Met die aantal moontlikhede vir die inrigting van die aanddiens word 'n veel groter verantwoordelikheid aan kerkrade, predikante en lidmate gegee. Daar kom groter vryheid van beweging en vir eie inisiatief.

Groter vryhede bring egter mee groter verantwoordelikheid in die gebruik daarvan. Enige goeie saak kan deur verkeerde gebruik ontaard. Saam met die vryheid kom 'n beroep om die vryheid reg te gebruik.

Verantwoordelikheid beteken dat die eredienste steeds in goeie orde en smaak en volgens die bedoeling van die Skrif, soos die eie Kerk dit 
verstaan, ingerig sal word. Dit mag nooit ontaard tot dienste wat vreemd is aan die belydenis en lewe van die kerk nie. Daar moet ook met groot omsigtigheid te werk gegaan word om mense nie daardeur af te skrik nie.

Leraars sal sulke dienste deeglik moet beplan en hulle moet vergewis van hoe ' $n$ bespreking sinvol gelei word. Leraars sal opgelei moet word om sommige moontlikhede wat aangegee is, sinvol te kan lei. Hulle sal mekaar ook daarin moet help. Die kommissies vir die erediens van die kerkraad, ring en sinode behoort stewige leiding te gee.

Omdat die moontlikhede wat hierbo aangegee is, die beste is wat uit die Skrif en geskiedenis en praktyk gevind kan word, kan dit met groot vrymoedigheid aangewend word, in die vertroue dat die Here self dit sal seën. Verder kan dit gehou word met die gebed dat die Here self die . aanddienste so sal vernuwe dat sy kerk daardeur sterker kan lewe en werk, dat die koninkryk kragtiger opgebou kan word, en bo alles dat die Here self die eer en verheerliking daardeur sal ontvang. 